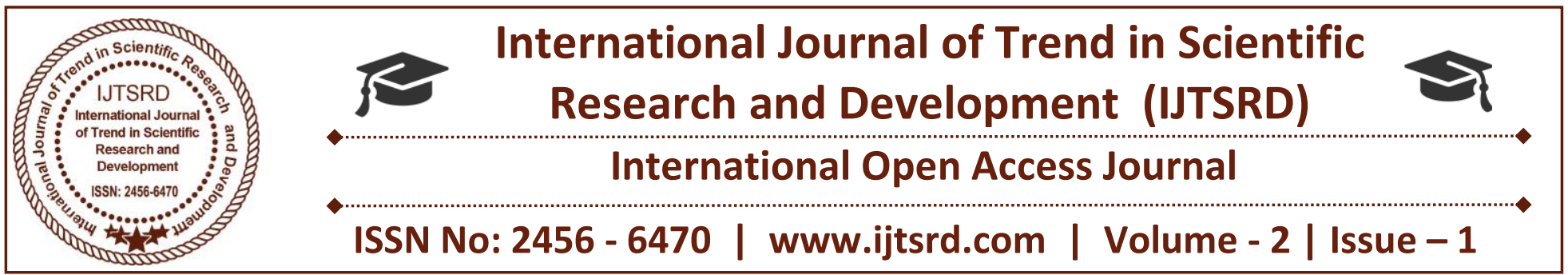

\title{
Use of Myth in Kanthapura: Parallelism between Ramayana and Kanthapura
}

\author{
Ishfaq Hussain Bhat \\ Department of English,University of Kashmir, \\ Thune, Kangan, Ganderbal, Jammu and Kashmir
}

\begin{abstract}
"I have written Puranas but not novels." - Raja Rao
\end{abstract}

Raja Rao (1908-2006) is one of the best Indian novelists writing in English. He occupies a central position in any discussion of Indian English literature. He is the foremost of those writers whose work has placed Indo-English literature on the map of world literatures. His first and best-known novel, Kanthapura (1938) earned him an international acclaim and acceptance as one of the major novelists in Indian English literature. Kanthapura is a novel dealing with the impact of the Gandhian freedom struggle on a remote South Indian village of that name. In this novel Raja Rao uses myths and legends to enrich the texture of the novel and impart to it a rare expansiveness, elevation and dignity. The paper attempts to show parallelism between Ramayana and Kanthapura by examining Raja Rao's artistic use of myth in the novel.

Keywords: Myth, Ramayana, Harikatha, Purana, freedom struggle

"I like to write like a Purana. I like the Puranic conception, in fact, that is the only conception of the novel for me. I don't want to write like a foreign novelist. I am very much an Indian and the Indian form is the Puranic form."

Raja Rao in his interview with Shiva Niranjan
Myth is a traditional story, especially one concerning the early history of a people or explaining a natural or social phenomenon, and typically involving supernatural beings or events. Myth is a sacred narrative because it holds religious or spiritual significance for those who tell it. It is an ahistorical, atemporal, ascientific, alogical explanation of the universe. Meenakshi

Mukherjee in her book "Myth as Technique in Twice Born Fiction" states that there are two broad ways in which an Indian writer uses myth: as a part of the digressional technique of which Raja Rao is the most outstanding expert; and the structural parallel where a mythical situation underlines the whole or part of the novel. In Kanthapura, Raja Rao uses two kinds of myths i.e., pan-Indian myth and localised myth. The pan-Indian myth which he uses is the use of wellknown epics which are easily communicable and easily comprehensible to all Indians e.g., Ramayana and Mahabharata. The localised myth is the legendary history of a place or a village e. g., Sthala-Purana. Raja Rao artistically juxtaposes these two types of myths with the freedom struggle of India in the novel.

Kanthapura is the story of an Indian village during the period of Gandhi's political activism. It gives the most vivid, graphic and realistic account of Gandhian freedom struggle in 1930s and its impact on the masses of India. The story is told by an old and simple hearted woman Achakka. Achakka's unlettered imagination provides Raja Rao the perfect opportunity to mingle God with men and infuse his narrative with 
other-worldliness. In this novel the freedom struggle is presented as a symbolic clash between the gods and the demons which, in turn, symbolizes a clash between the forces of good and evil. Moorthy, the central figure, is a staunch

Gandhi man who inspires and explains to the villagers the significance of Gandhi's struggle for independence

Kanthapura is a perfect combination of myth, legends, folk-tales and symbols. The local goddess Kenchamma symbolizes a protector, invoked by the villagers for the success of the freedom struggle. Gandhi is given the status of a god as he is first identified with Rama for killing the demon Ravana (Britishers) and then with Krishna killing Kaliya. Satyagrah has been presented as a religious ceremony. In Ramayana, Rama goes to the door of Varnas and enlightens them to destroy the evil Ravana, in the same way Moorthy goes about from door to door carrying the message of Gandhi. In Kanthapura Raja Rao emphasizes the contemporary importance of the myth:

"There is no village in India, however mean, that has not a rich Sthala-Purana, or a legendary history of its own. Some god or god-like hero has passed by the village - Rama might have rested under this papal tree: Sita might have dried her clothes, after her bath on this yellow stone; or the Mahatama himself, on one of his many pilgrimages throughout the country might have slept in this hut."

\section{( Kanthapura, 5)}

Kanthapura is replete with myths. The village, Kanthapura, has a local goddess Kenchamma who has a mythical semblance of the Puranic tales. She protects the villages from famine and diseases. The people have full faith in her and believe the story that Kenchamma killed the demon which squandered at the countryside that is why the colour of the hill is red. The villagers praise their goddess in these words:

“Kenchamma, Kenchamma,

Goddess benign and bounteous,

Mother of earth, blood of life,

Harvest - queen- rain crowned,
Kenchamma, Kenchamma,

Goddess benign and bounteous.”

( Kanthapura, 10)

In Kanthapura, Raja Rao attempts to show a remarkable parallelism between Ramayana and Kanthapura. He represents swaraj as Sita, Rama as Mahatama and Bharatha as Nehru. Raja Rao compares Rama's journey to Lanka to bring Sita to Gandhi's trip to 'Red-man's' country to participate in the second round table conference. The people believe that as Rama brought Sita back, Gandhi would bring swaraj for them:

"They say the Mahatama will go to the Red-Man's country and he will get us Swaraj. He will bring us Swaraj, the Mahatam. And we shall be all happy. And Rama will come back from exile and Sita will be with him, for Ravana will be slain and Sita freed, he will come back with Sita on his right in the chariot of the air and brother Bharatha will go to meet them with the worshipped sandal of the master on his head. And as they enter Ayodhya, there will be a rain of flowers."

\section{( Kanthapura, 183)}

Raja Rao compares the women characters of the novel with various forms of goddesses. Ratna is represented as Shakti when she takes over Moorthy after his arrest and leads the satyagrah movement against the British. The confrontation of women with the police has artistically been portrayed. All women act as one like Shakti. Ratna gives strength to all of them by saying:

"Well, 'we shall fight the police for Kenchamma's sake, and if the rapture of devotion is in you, the lathi will grow as soft as butter and as supple as a silken thread, and you will hum out the name of the Mahatama,' and we all grow dumb and mutter 'yes, sister, yes'."

\section{( Kanthapura, 112)}

Jayaramachar, the Harikatha man, in his Harikathas represents Goddess Parvathy's struggle for Lord Shiva as India's struggle for freedom. The three eyes of Lord Shiva represent Self-purification, unity, making and wearing of Khadi. Jayaramachar while serving political ends says: 
"Shiva is the three - eyed; and swaraj too is three- eyed: self-purification, Hindu-

Moslem unity, Khadder."

\section{(Kanthapura, 16)}

In one of the first of his Harikathas, he elegantly mingles Ramayana with the freedom struggle of India and raises Gandhi to the level a god by comparing him with Shiva:

"In the great Heavens Brahma the self-created One was lying on his serpent, when the sage Valmiki entered... 'Oh, learned sire, what brings you to this distant world?' asked Brahma. [Valmiki replies] 'I have come to bring you sinister news. Far down on the Earth you chose as your chief daughter Bharatha, the goddess of wisdom and well-being...O Brahma, you who sent us the Prince propagators of the Holy Law and Sages that smote the darkness of ignorance, you have forgotten us so long that the Red-men have come from across the seas and the oceans to trample on our wisdom and to spit on virtue itself. They have come to bind us and to whip us, to make our women die milkless and our men die ignorant. O Brahma design to send us one of your gods so that he may incarnate on Earth and bring back light and plenty to your enslaved daughter...' 'O Sage' pronounced Brahma, 'is it greater for you to ask or for me to say yes? Siva himself will forthwith go and incarnate on Earth and free my beloved daughter from her enforced slavery. Pray seat yourself, and the messengers of Heaven shall fly to Kailas and Siva be informed of it...There was born in a family in Gujarat a son such as the world has never beheld."

\section{(Kanthapura 17-18)}

Jayaramachar again raises Gandhi to the level of a god by identifying his activities with one particular feat of Krishna:

"You remember how Krishna when he was but a babe of four, had begun to fight the serpent Kali, so too our Mohandas began to fight, against the enemies of the country...Men followed him, as they did Krishna, the flute-prayer; and so he goes from village to village, to slay the serpent of the foreign rule."

( Kanthapura, 18”
A. N. Dwivedi acknowledging thae artiatic parlellism between Kanthapura and Ramayana states:

"The mythical-cum-symbolic design of this novel coupled with its political and social overtones prompts us to believe that the novelist was very serious about his business in co-minglig fact and fiction, and reality and illusion, the concrete and abstract, and by doing so he added an additional punch and meaning to his utterances."

\section{( Dwivedi, 162)}

Raja Rao artistically compares the freedom struggle of India with Ramayana. He juxtaposes the present and the past by using myths in the novel to glorify the present. Moreover, the description of Ramakrishna's death in the novel is reminiscent of the account of Nature's response to the death of Karna in the Mahabharatha:

“...when Karna fell, the rivers stood still...The earth uttered loud roars...The mountains with their forest began to tremble and all creatures felt pain." (Roy trans. The Mahabharatha, 1956; 283)

In Kanthapura, Ramakrishna's death is also described in mythical tones:

"And that night, as no other night, no cow would give its milk...and calves pranced about their mothers and groaned...Lord may such be the path of our outgoing soul."( Kanthapura, 101)

\section{(Mithapalli, 83)}

The novel is replete with rituals which lends a mythical halo and fervor to the novel.

Through Achakka's narrations, Raja Rao achieves a deft and artistic blending of the mythical and the real. As a result, the novel becomes a "glorious myth... as profound as a shashtra, and as prolific as a 'purana,' yet in its brevity and verbal economy, it excels in capturing excessive critical imagination." (Mittapalli, 84). Thus Raja Rao shows the parallelism between Ramayana and Kanthapura. He uses myth to glorify the present and to impart the novel the dignity and status of an epic or Purana. By the use of the mythical technique, Raja Rao has enriched the texture of the novel and has imparted to it a rare expansiveness, elevation and diginity. It is the mythical technique 
used by Raja Rao that makes Kanthapura a unique novel.

\section{Works Cited:}

1) Rao, Raja. Kanthapura. Orient Paperbacks. New Delhi. 2008. Print.

2) Mittapalli, Rajesh, Piciucco, Piet Paolo. The Fiction of Raja Rao: Critical Studies. Atlantic Publishers and Distributers. New Delhi. 2001. Print.

3) Dwivedi, A. N. Papers on Indian Writing in English. Atlantic Publishers and Distributors. New Delhi.

4) Mukherjee, Meenakshi. Myth as Technique in Twice Born Fiction. Heinemann, New Delhi. 1974.

5) Iyenger, K. R. Srinivasa. Indian Writings in English. Sterling publishers. New Delhi. 1993. Print.

6) Narasimhaiah, C. D. Makers of Indian English Literatures. Pencraft international. New Delhi.2000.Print.

\section{Web Sources:}

An Interview with Raja Rao by P. Bayapa Reddy in Aspects id Contemporary World Literature. 2008. 